\title{
Decitabine inhibits the proliferation of human T-cell acute lymphoblastic leukemia molt4 cells and promotes apoptosis partly by regulating the PI3K/AKT/mTOR pathway
}

\author{
GANG ZHANG $^{1}$, XIAOHUI GAO ${ }^{2}$, XIAOYAN ZHAO ${ }^{1}$, HAIBING WU $^{1}$, MINCHAO YAN $^{1}$, \\ YUAN LI ${ }^{1}$, HUI ZENG ${ }^{1}$, ZHAONING JI $^{3}$ and XIAOJUN GUO ${ }^{1}$ \\ Departments of ${ }^{1}$ Hematology and ${ }^{2}$ Pediatrics, First Affiliated Hospital of Jiaxing University, \\ Jiaxing, Zhejiang 314000; ${ }^{3}$ Department of Medical Oncology, The Cancer Center, \\ Yijishan Hospital of Wannan Medical College, Wuhu, Anhui 241001, P.R. China
}

Received May 13, 2019; Accepted September 11, 2020

DOI: 10.3892/ol.2021.12601

\begin{abstract}
T cell acute lymphoblastic leukemia (T-ALL) is a highly aggressive hematological cancer; however, there is a lack of effective chemotherapeutic or targeted drugs for the treatment of T-ALL. Decitabine is a DNA demethylation agent but it has not been used for T-ALL treatment. Therefore, the present study aimed to assess the inhibitory effect of decitabine on T-ALL molt4 cells and determine its regulatory role in the $\mathrm{PI} 3 \mathrm{~K} / \mathrm{AKT} / \mathrm{mTOR}$ pathway. Molt4 cells were stimulated with decitabine in vitro, after which cell proliferation, apoptosis and cell cycle analyses were performed to assess cell viability. Subcellular morphology was observed using transmission electron microscopy. Expression levels of phosphate and tension homology (PTEN), genes involved in the PI3K/AKT/mTOR pathway and the corresponding downstream genes were analyzed using reverse transcription-quantitative PCR and western blotting. The results showed that decitabine induced apoptosis, inhibited proliferation and arrested molt 4 cells in the $\mathrm{G}_{2}$ phase. Following decitabine intervention, an increase in the number of lipid droplets, autophagosomes and mitochondrial damage was observed. At concentrations of 1 and $10 \mu \mathrm{M}$, decitabine downregulated the expression of PI3K, AKT, mTOR, P70S6 and eukaryotic initiating factor 4E-binding protein 1, which in turn upregulated PTEN expression; however, $50 \mu \mathrm{M}$ decitabine downregulated PTEN levels. Overall, these results demonstrated that decitabine reduced the viability of molt4 cells partly by inhibiting the PI3K/AKT/mTOR pathway via PTEN, especially at low decitabine concentrations.
\end{abstract}

Correspondence to: Professor Xiaojun Guo, Department of Hematology, First Affiliated Hospital of Jiaxing University, 1882 Zhonghuan South Road, Jiaxing, Zhejiang 314000, P.R. China E-mail: 921950782@qq.com

Key words: T cell acute lymphoblastic leukemia, decitabine, DNA methylation, phosphatase and tensin homolog, PI3K/AKT/mTOR pathway

\section{Introduction}

T cell acute lymphoblastic leukemia (T-ALL) is a highly aggressive hematological cancer caused by the malignant transformation of $\mathrm{T}$ cell progenitor cells. T-ALL accounts for $10-15 \%$ and $20-25 \%$ of pediatric and adult ALL cases, respectively (1). Compared with B cell ALL, T-ALL has lower event-free survival (EFS) and 5-year overall survival (OS) rate (2), as well as a higher recurrence rate, incidence of chemotherapeutic resistance and a poorer prognosis (3). At present, the therapeutic outcomes of T-ALL remain unsatisfactory, and $20 \%$ of patients experience recurrence after chemotherapy (4). Therefore, novel combination chemotherapeutic or targeted drug regimens are required to improve therapeutic effects and reduce the rates of drug resistance (5).

The PI3K/AKT/mTOR pathway is closely associated with the occurrence, proliferation and metastasis of blood cancer and other malignant tumors $(6,7)$. Abnormal activation of the $\mathrm{PI} 3 \mathrm{~K} / \mathrm{AKT} / \mathrm{mTOR}$ pathway is a common feature of cancer, characterizing T-ALL diseases and often leading to the malignant transformation of T cells (8). Phosphate and tension homology (PTEN) is a tumor suppressor gene that can prevent the proliferation of cancer cells and promotes apoptosis by dephosphorylating phosphatidylinositol (3-5)-trisphosphate (PIP3) to phosphatidylinositol (4,5)-bisphosphate (PIP2). This thereby inhibits the activation of the PI3K/AKT/mTOR pathway (9). The PTEN gene is deleted or weakly expressed in leukemia, which was found to be associated with promoter methylation (9). Furthermore, downregulation of PTEN expression leads to continuous activation of the PI3K/AKT signaling pathway $(10,11)$.

In the epigenetic regulation of ALL cells, key microRNAs (miRs), including miR-21, -22, -93-a and -221, activate the $\mathrm{PI} 3 \mathrm{~K} / \mathrm{AKT} / \mathrm{mTOR}$ signaling pathway through PTEN inhibition, thus affecting the migration activity of ALL cancer cells, drug resistance, and adverse outcomes in pediatric patients (12). Another common epigenetic change that mediates tumor occurrence is DNA methylation, which leads to the silencing of tumor suppressor genes (TSGs), thereby inducing the transformation of normal cells into cancer cells (13). 
Therefore, inhibiting DNA methylation and activating silent TSGs could serve as a new approach for cancer therapy (14). Decitabine is a demethylation agent exerting antitumor effects that can reverse the methylation of $\mathrm{CpG}$ sites and restore methylation patterns in the silent TSGs (15).

Decitabine has been used for the treatment of myelodysplastic syndrome and acute/chronic myeloid leukemia (16-18). However, decitabine has not been used for T-ALL treatment, and basic research demonstrating its therapeutic effect for T-ALL is limited. The present study aimed to investigate the inhibitory effects of decitabine on the T-ALL molt4 cell line. In addition, decitabine-mediated regulation of PTEN expression, genes in the PI3K/AKT/mTOR pathway and downstream oncogenes were analyzed.

\section{Materials and methods}

Cell lines and cell culture. Contaminant-free molt4 cell line with short tandem repeat lineage certification was provided by Jiangsu KGI Biotechnology Co., Ltd.. The culture medium contained 90\% RPMI-1640 (Gibco; Thermo Fisher Scientific, Inc.) and $10 \%$ fetal bovine serum (Shanghai ExCell Biology, Inc.). Cells were cultured at $37^{\circ} \mathrm{C}$ with $5 \% \mathrm{CO}_{2}$ in a saturated humidity environment. Upon reaching 80-90\% confluence, cells were centrifuged at $220 \mathrm{x}$ g for $5 \mathrm{~min}$ at room temperature and passaged at a 1:3 ratio. Further experiments were carried out, when the cells reached the required density.

Cell proliferation assay. Molt4 cells were cultured in 96-well culture plates at a concentration of $5 \times 10^{4}$ cells $/ \mathrm{ml}$ and $100 \mu 1$ cell culture medium per well. After $24 \mathrm{~h}$ of incubation at $37^{\circ} \mathrm{C}$, the medium was discarded, and the cells were washed with phosphate buffer saline (PBS). Culture medium containing varying concentrations of decitabine $(0.00625,0.0125,0.025$, $0.05,0.1,0.5,1.0,5.0,10.0,50.0$, and $100 \mu \mathrm{M})$ was added for the cell proliferation assay. A negative control (without decitabine) was also prepared and added to eight wells in each group. The 96-well plate cells were cultured for 24, 48, 72 and $96 \mathrm{~h}$ and treated with $10 \mu \mathrm{l}$ Cell Counting kit (CCK)-8 (Dojindo Molecular Technologies, Inc.) for $3 \mathrm{~h}$ according to the manufacturer's protocol. After blending, optical density (OD) was measured at $\lambda=450 \mathrm{~nm}$. The half maximal inhibitory concentration $\left(\mathrm{IC}_{50}\right)$ was calculated using probability unit weighted regression (Bliss method), and the drug inhibition rate was calculated utilizing the following formula (19): Inhibition rate $(\%)=$ negative control group-experimental group/negative group $x 100$. The data are based on three independent experiments with four replicates per sample in each experiment.

Apoptosis analysis. Annexin V-FITC/PI double staining kit (Jiangsu Kaiji Biotechnology Co., Ltd.) was used to detect cell apoptosis, both early (Annexin V-FITC+/PI-) and late stage (Annexin V-FITC+/PI+). Logarithmic phase cells were inoculated into 6-well plates. After cell adherence, the aforementioned culture medium was replaced with medium containing different concentrations of decitabine $(1,10$ and $50 \mu \mathrm{M})$. A negative control without decitabine was also prepared. After $96 \mathrm{~h}$ of decitabine stimulation at $37^{\circ} \mathrm{C}$, the cells were collected, centrifuged at $300 \mathrm{x}$ g at $37^{\circ} \mathrm{C}$ for $5 \mathrm{~min}$ and washed with PBS. Next, the cell density was adjusted to
$5 \times 10^{5}$ cells in $500 \mu \mathrm{l}$ binding buffer (Jiangsu KGI Biotechnology Co., Ltd.) using an Automated Cell Counter (Thermo Fisher Scientific, Inc.), and subsequently $5 \mu \mathrm{l}$ Annexin V-FITC and $5 \mu \mathrm{l}$ propidium iodide were added to the $500-\mu 1$ cell suspension for incubation at $37^{\circ} \mathrm{C}$ for $10 \mathrm{~min}$ in dark. Apoptotic cells were detected using flow cytometry with FACSCalibur (CellQuest Pro, version 6.0, BD Biosciences) after 5 to $15 \mathrm{~min}$ of reaction in the dark.

Cell cycle detection. Logarithmic growth phase cells were inoculated into six-well plates, and the culture medium was replaced with medium containing different concentrations of decitabine $(1,10$ and $50 \mu \mathrm{M})$ after adherence. After $96 \mathrm{~h}$ in culture at $37^{\circ} \mathrm{C}$, cells were digested with $0.25 \%$ pancreatin (without EDTA) and washed with PBS. Subsequently, $5 \times 10^{5}$ cells were collected and fixed with $70 \%$ ethanol overnight at $4{ }^{\circ} \mathrm{C}$. After washing with $70 \%$ PBS and centrifugation at $220 \mathrm{x} \mathrm{g}$ for $5 \mathrm{~min}$ at room temperature, cells were treated with $100 \mathrm{ml}$ RNase A and incubated at $37^{\circ} \mathrm{C}$ for $30 \mathrm{~min}$. Next, cells were incubated with $400 \mu$ l PI dye (Jiangsu Kaiji Biotechnology Co., Ltd.) and mixed at $4^{\circ} \mathrm{C}$ for $30 \mathrm{~min}$ in the dark. Red fluorescence was measured (FACSCalibur; BD Biosciences) and analyzed (FACScan software; version 6.0; BD Biosciences) at the re-excitation wavelength of $488 \mathrm{~nm}$. Three independent experiments were carried out.

Transmission electron microscope (TEM) analysis. Molt4 cells stimulated with varying concentrations of decitabine $(1,10$ and $50 \mu \mathrm{M})$ and the negative control were analyzed after $96 \mathrm{~h}$ of incubation at $37^{\circ} \mathrm{C}$. The cells were washed with PBS, placed in fresh tubes, fixed with PBS containing $2.5 \%$ glutaraldehyde for $2 \mathrm{~h}$ at $4^{\circ} \mathrm{C}$, and washed with $0.1 \mathrm{M}$ PBS. Next, cells were post-fixed with $1 \%$ osmium acid solution for $3 \mathrm{~h}$ at $4^{\circ} \mathrm{C}$, dehydrated sequentially in 50,70, 90 and $100 \%$ ethanol for 15 min each (three times in $100 \%$ ethanol), embedded in epoxy resin and cut into 50-nm thick sections. After 3\% uranium citrate staining for $30 \mathrm{~min}$ at room temperature, samples were observed under a TEM (magnification, x50) and images were captured.

Reverse transcription-quantitative $(R T-q) P C R$. Cells were collected after stimulation with varying concentrations of decitabine $(0,1,10$ and $50 \mu \mathrm{M})$. Cells were treated with $1 \mathrm{ml}$ TRIzol $^{\circledR}$ (Invitrogen; Thermo Fisher Scientific, Inc.), incubated with chloroform for $3 \mathrm{~min}$ at room temperature, and then centrifuged at $12,000 \mathrm{x} \mathrm{g}$ at $4^{\circ} \mathrm{C}$ for $15 \mathrm{~min}$. The supernatant was collected, mixed with $0.6 \mathrm{ml}$ of isopropanol for $10 \mathrm{~min}$, and centrifuged at $12,000 \mathrm{~g}$ at $4^{\circ} \mathrm{C}$ for $10 \mathrm{~min}$. After discarding the supernatant, $70 \%$ ethanol was added to the cells, and they were centrifuged at $7,500 \mathrm{~g}$ at $4^{\circ} \mathrm{C}$ for $10 \mathrm{~min}$. RNA concentration was measured after discarding the supernatant and suspending the pellet in DNase/RNase-free ultrapure water (Table SI). Reverse transcription was performed to synthesize cDNA (catalog no. K1632; Fermentas; Thermo Fisher Scientific, Inc.). After PCR amplification, the reaction system contained $10 \mu \mathrm{l}$ real-time PCR Master Mix (catalog no. EP0702; Fermentas; Thermo Fisher Scientific, Inc.), $1 \mu 1$ DNA template, $2 \mu 1$ each primer and $7 \mu \mathrm{l} 0.1 \%$ DEPC water. The thermocycling conditions were as follows: Pre-denaturation at $95^{\circ} \mathrm{C}$ for $5 \mathrm{~min}$; 40 cycles of $95^{\circ} \mathrm{C}$ for $15 \mathrm{sec}, 60^{\circ} \mathrm{C}$ for $20 \mathrm{sec}$ and $72^{\circ} \mathrm{C}$ for 
Table I. Primers of target genes for reverse transcription-quantitative PCR detection.

\begin{tabular}{lll}
\hline Target gene & \multicolumn{1}{c}{ Forward sequence, 5'-3' $^{\prime}$} & \multicolumn{1}{c}{ Reverse sequence, 5'-3' } \\
\hline 4EBP1 & CAAGGGATCTGCCCACCATT & AACTGTGACTCTTCACCGCC \\
AKT & GGCTATTGTGAAGGAGGGTTG & TCCTTGTAGCCAATGAAGGTG \\
GAPDH & TGTTGCCATCAATGACCCCTT & CTCCACGACGTACTCAGCG \\
mTOR & ATTTGATCAGGTGTGCCAGT & GCTTAGGACATGGTTCATGG \\
P70S6 & CGGGTACTTGGTAAAGGGGG & TGCCTTTTAAGCACCTTCATGG \\
PI3K & ATGCAAATTCAGTGCAAAGG & CGTGTAAACAGGTCAATGGC \\
PTEN & CAAGATGATGTTTGAAACTATTCCAATG & CCTTTAGCTGGCAGACCACAA
\end{tabular}

4EBP1, eukaryotic initiating factor 4E-binding protein 1; PTEN, phosphate and tension homology.

$40 \mathrm{sec}$; extension at $95^{\circ} \mathrm{C}$ for $15 \mathrm{sec}, 60^{\circ} \mathrm{C}$ for $1 \mathrm{~min}$ and $95^{\circ} \mathrm{C}$ for $15 \mathrm{sec}$, the fluorophore (cat no. DA7600; Zhongshan Bio Tech Co., Ltd.). The customized primers used for amplification are listed in Table I and GAPDH was used as the control (Jiangsu KeyGen Biotechnology Co., Ltd.). Three independent experiments were carried out. The relative expressions of the genes were calculated utilizing the $2^{-\Delta \Delta \mathrm{Cq}}$ method (20).

Western blotting. Cells stimulated with varying concentrations of decitabine $(0,1,10$ and $50 \mu \mathrm{M})$ were collected. Total proteins were extracted after cell lysis (no. KGP701-100; Cell lysis buffer for Western; Jiangsu KeyGen Biotechnology Co., Ltd.). The protein concentration was determined using the bicinchoninic acid method. The OD value was measured at the wavelength of $520 \mathrm{~nm}$ (Jiangsu KeyGen Biotechnology Co., Ltd.).

Sodium dodecyl sulfate-polyacrylamide gel electrophoresis (SDS-PAGE) was performed using a $12 \%$ separating gel and $5 \%$ layering gel. For sample preparation, $15 \mu \mathrm{l}$ protein lysate was mixed with $5 \mu \mathrm{l}$ SDS buffer and sampled. The membrane was transferred after electrophoresis at the voltage of 60 to $90 \mathrm{~V}$. After cleaning and sealing the cellulose nitrate membrane containing protein, the corresponding antibodies against eukaryotic initiating factor 4E-binding protein (4EBP)1, AKT, MTOR, P70S6, PI3K, PTEN and GAPDH were added, and the membranes were incubated overnight at $4^{\circ} \mathrm{C}$. After washing with $0.05 \%$ Tween-20 (catalog no. TA-999-TT; Thermo Fisher Scientific, Inc.), goat anti-rabbit secondary antibodies were added. Antibody details are presented Table SII. An enhanced chemiluminescence kit (Jiangsu KGI Biotechnology Co., Ltd.) was used for coloration and to capture images for analysis. Signal intensities were quantified utilizing the Gel-Pro32 analyzer software (Media Cybernetics, Inc.). The relative expression ratio of target proteins was calculated as follows: Relative expression ratio of target protein integrated optical density (IOD)/GAPDH IOD. Three independent experiments were carried out and Gel-Proanalyzer version 4.0 software (Media Cybernetics) was used for densitometry.

Statistical analysis. Data are presented as mean \pm standard deviation. Unpaired Student's t-tests and Mann-Whitney tests were used to compare significant differences between groups. Normality and homogeneity of variance were calculated. Then one-way ANOVA was performed to compare differences among the groups with Tukey's post hoc test. SPSS version 18 (SPSS Inc.) was used for statistical analysis. $\mathrm{P}<0.05$ was considered statistically significant.

\section{Results}

Decitabine inhibits the proliferation of molt4 cells. The effects of different decitabine concentrations on molt4 cell proliferation at various time points are presented in Table II. Overall, after $24 \mathrm{~h}$ of incubation with different concentrations of decitabine, it was observed that $100 \mu \mathrm{M}$ decitabine had the greatest inhibitory effect on cell proliferation at $18.59 \%(\mathrm{P}<0.01)$. The inhibitory rate gradually decreased with decreasing decitabine concentrations, reaching-2.62\% at $0.00625 \mu \mathrm{M}(\mathrm{P}=0.035)($ Fig. $1 \mathrm{~A})$. The inhibition rate of cell proliferation was $32.56 \%$ at $100 \mu \mathrm{M}$ decitabine after $48 \mathrm{~h}$ of treatment $(\mathrm{P}<0.01)$. Lowering the decitabine concentration decreased the inhibition rate to $1.15 \%$ at $0.00625 \mathrm{mM}$ $(\mathrm{P}=0.286)$ (Fig. 1B). Treatment with $100 \mu \mathrm{M}$ decitabine for $72 \mathrm{~h}$ led to an inhibition rate of $54.20 \%(\mathrm{P}<0.01)$. Treatment with lower concentrations of decitabine reduced the inhibition rate to $2.81 \%$ at $0.00625 \mu \mathrm{M}(\mathrm{P}=0.179)$. In addition, the $\mathrm{IC}_{50}$ was $84.461 \mu \mathrm{M}$ after $72 \mathrm{~h}$ of treatment (Fig. 1C). After $96 \mathrm{~h}$ of stimulation, the inhibition rate was $69.85 \%$ at $100 \mu \mathrm{M}$ decitabine. Moreover, the inhibition rate gradually decreased to $18.48 \%$ at $0.00625 \mu \mathrm{M}$ decitabine. Therefore, the $\mathrm{IC}_{50}$ was $10.113 \mu \mathrm{M}$ after $96 \mathrm{~h}$ of treatment (Fig. 1D). These data demonstrated that decitabine inhibited the proliferation of molt 4 cells in a dose and time-dependent manner.

Decitabine induces molt4 apoptosis. Apoptosis was detected using Annexin V-FITC/PI double staining. Flow cytometry analysis showed that the percentage of apoptotic cells in the negative control group was $2.27 \%$ (Fig. 2A). Cells treated with 1,10 and $50 \mu \mathrm{M}$ decitabine exhibited apoptosis rates of 20.9, 43.7 and $62.38 \%$, respectively (Fig. 2B-E). Decitabine induced molt 4 cells apoptosis in a dose-dependent manner.

Effect of decitabine on the cell cycle. In cells that were not treated with decitabine, the percentage of cells in the $G_{1}, S$ and $\mathrm{G}_{2}$ phases were $51.09,35.52$ and $13.39 \%$, respectively (Fig. 3A). The percentage of cells in the $G_{1}, S$ and $G_{2}$ phases were $49.32,28.26$ and $22.42 \%$, respectively, after $48 \mathrm{~h}$ 
Table II. Effects of different concentrations of decitabine on the inhibitive rate of molt4 cells proliferation at various time points.

\begin{tabular}{|c|c|c|c|c|c|c|c|c|}
\hline \multirow[b]{3}{*}{ Concentration, $\mu \mathrm{M}$} & \multicolumn{8}{|c|}{ Time after intervention, $\mathrm{h}$} \\
\hline & \multicolumn{2}{|c|}{24} & \multicolumn{2}{|c|}{48} & \multicolumn{2}{|c|}{72} & \multicolumn{2}{|c|}{96} \\
\hline & $\mathrm{OD} \pm \mathrm{SD}$ & $\begin{array}{c}\text { Inhibition } \\
\text { rate, } \%\end{array}$ & $\mathrm{OD} \pm \mathrm{SD}$ & $\begin{array}{c}\text { Inhibition } \\
\text { rate, } \%\end{array}$ & $\mathrm{OD} \pm \mathrm{SD}$ & $\begin{array}{l}\text { Inhibition } \\
\text { rate, } \%\end{array}$ & $\mathrm{OD} \pm \mathrm{SD}$ & $\begin{array}{c}\text { Inhibition } \\
\text { rate, } \%\end{array}$ \\
\hline $\mathrm{NC}$ & $2.25 \pm 0.03$ & - & $2.05 \pm 0.04$ & - & $2.01 \pm 0.04$ & - & $2.50 \pm 0.05$ & - \\
\hline 100 & $1.83 \pm 0.09^{b}$ & 18.59 & $1.38 \pm 0.06^{\mathrm{b}}$ & 32.56 & $0.92 \pm 0.03^{\mathrm{b}}$ & 54.20 & $0.75 \pm 0.04^{\mathrm{b}}$ & 69.85 \\
\hline 50 & $1.90 \pm 0.07^{b}$ & 15.69 & $1.47 \pm 0.05^{\mathrm{b}}$ & 27.95 & $1.06 \pm 0.07^{b}$ & 47.15 & $0.84 \pm 0.08^{b}$ & 66.36 \\
\hline 10 & $1.91 \pm 0.08^{\mathrm{b}}$ & 15.38 & $1.69 \pm 0.06^{\mathrm{b}}$ & 17.20 & $1.71 \pm 0.07^{b}$ & 14.96 & $1.39 \pm 0.07^{b}$ & 44.46 \\
\hline 5 & $1.95 \pm 0.05^{\mathrm{b}}$ & 13.31 & $1.71 \pm 0.07^{\mathrm{b}}$ & 16.25 & $1.72 \pm 0.02^{\mathrm{b}}$ & 14.56 & $1.48 \pm 0.06^{\mathrm{b}}$ & 40.77 \\
\hline 1 & $2.08 \pm 0.08^{b}$ & 7.51 & $1.84 \pm 0.05^{\mathrm{b}}$ & 9.96 & $1.73 \pm 0.08^{\mathrm{b}}$ & 13.98 & $1.80 \pm 0.10^{\mathrm{b}}$ & 27.97 \\
\hline 0.5 & $2.20 \pm 0.02^{\mathrm{a}}$ & 2.34 & $1.88 \pm 0.07^{\mathrm{b}}$ & 8.13 & $1.81 \pm 0.08^{\mathrm{b}}$ & 10.00 & $1.81 \pm 0.10^{\mathrm{b}}$ & 27.39 \\
\hline 0.1 & $2.21 \pm 0.07$ & 1.98 & $1.88 \pm 0.07^{\mathrm{b}}$ & 7.90 & $1.82 \pm 0.08^{\mathrm{b}}$ & 9.30 & $1.83 \pm 0.04^{\mathrm{b}}$ & 26.73 \\
\hline 0.05 & $2.30 \pm 0.04$ & -2.22 & $1.94 \pm 0.07^{\mathrm{a}}$ & 5.39 & $1.85 \pm 0.06^{\mathrm{b}}$ & 8.02 & $1.84 \pm 0.05^{b}$ & 26.36 \\
\hline 0.025 & $2.27 \pm 0.04$ & -0.67 & $1.94 \pm 0.08^{\mathrm{a}}$ & 5.22 & $1.86 \pm 0.05^{\mathrm{b}}$ & 7.40 & $1.94 \pm 0.06^{\mathrm{b}}$ & 22.24 \\
\hline 0.0125 & $2.33 \pm 0.07$ & -3.27 & $2.00 \pm 0.03$ & 2.08 & $1.95 \pm 0.04$ & 2.85 & $2.00 \pm 0.10^{\mathrm{b}}$ & 20.12 \\
\hline 0.00625 & $2.31 \pm 0.04^{\mathrm{a}}$ & -2.62 & $2.02 \pm 0.03$ & $1.15 \%$ & $1.95 \pm 0.07$ & 2.81 & $2.04 \pm 0.05^{\mathrm{b}}$ & 18.48 \\
\hline
\end{tabular}

${ }^{\mathrm{a}} \mathrm{P}<0.05$ and ${ }^{\mathrm{b}} \mathrm{P}<0.01$ vs. NC. OD, optical density; $\mathrm{NC}$, negative control.

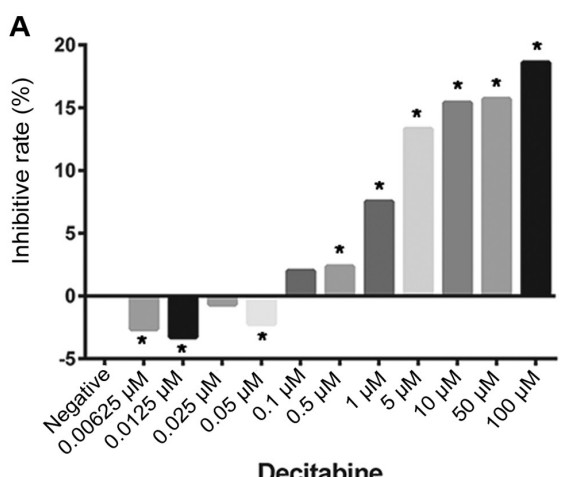

Decitabine

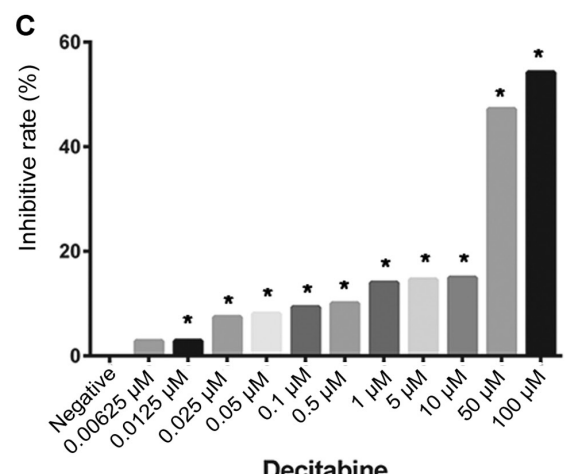

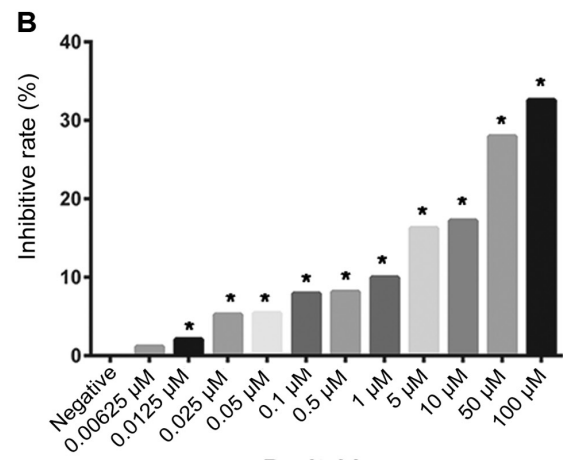

Decitabine

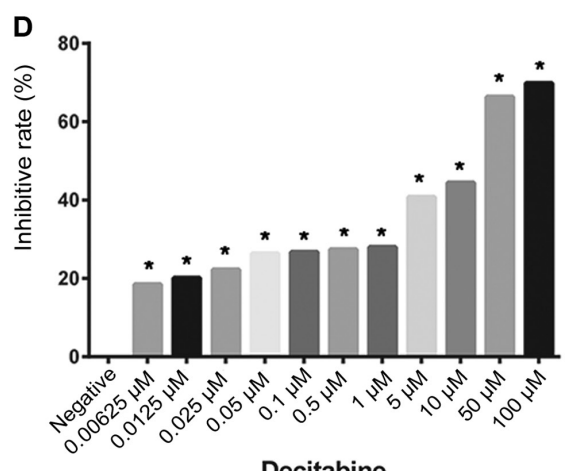

Decitabine

Figure 1. Effect of different decitabine concentrations on the inhibition of molt4 cells proliferation at (A) 24, (B) 48, (C) 72 and (D) 96 h. The presented data are based on three independent experiments with four replicates per treatment in each experiment. "P<0.05 vs. negative control.

treatment with $50 \mu \mathrm{M}$ decitabine (Fig. 3B). After $72 \mathrm{~h}$ treatment with $50 \mu \mathrm{M}$ decitabine, the percentage of cells in the $\mathrm{G}_{1}$, $\mathrm{S}$ and $\mathrm{G}_{2}$ phases were $46.00,25.57$ and $28.44 \%$ (Fig. 3C). The percentage of cells in the $G_{1}, S$ and $G_{2}$ phases were 45.13, 19.56 and $35.31 \%$, respectively, after $96 \mathrm{~h}$ treatment with $50 \mu \mathrm{M}$ decitabine (Fig. 3D). Increasing the decitabine concentration decreased the proportion of cells in the $S$ phase and gradually increased the proportion of cells in the $G_{2}$ phase (Fig. 3A-D). Three independent experiments were carried out and provided very similar results. These results indicated that the majority 

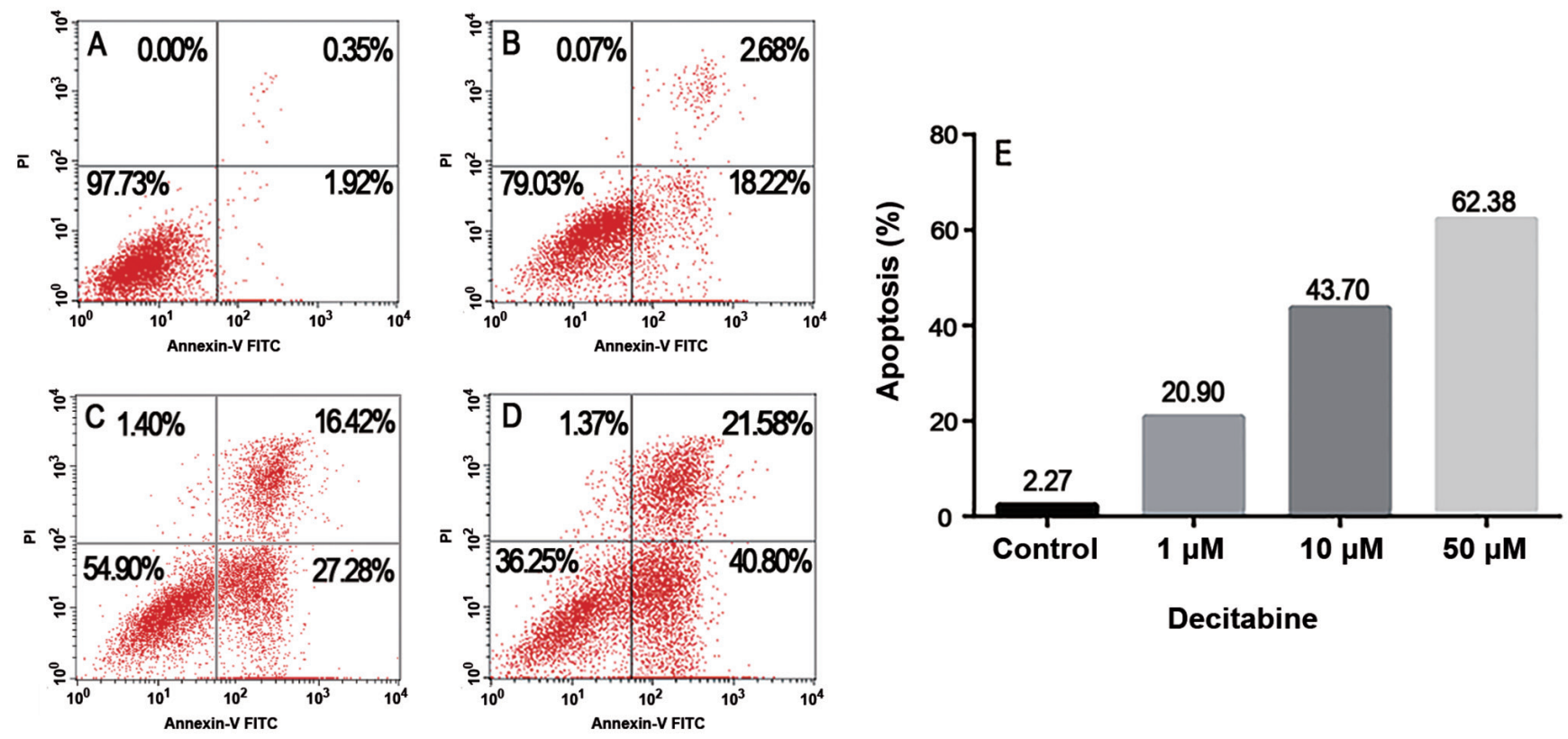

Figure 2. Effect of different decitabine concentrations on the apoptosis of molt4 cells at 96 h. (A) Negative control. (B) $1 \mu \mathrm{M}$. (C) $10 \mu \mathrm{M}$. (D) $50 \mu \mathrm{M}$. (E) Bar chart showing the percentage of apoptotic cells. Quadrant meaning: Upper left, Annexin V-/PI +; upper right, Annexin V+/PI+; lower left, Annexin V-/PI-; lower right, Annexin V+/PI-

of molt 4 cells were arrested in the $G_{2}$ phase after decitabine stimulation.

TEM detection. Molt4 cells that were not treated with decitabine showed normal cell morphology, and lipid droplets were observed in the cytoplasm of a subset of the cells (Fig. 4A and B). The number of lipid droplets (Fig. 4C and D) and damaged mitochondrial cells (Fig. 4C-H) increased gradually with higher decitabine concentrations. Autophagic body-like structures were observed in the cells after treatment with $50 \mu \mathrm{M}$ decitabine (Fig. 4H). The effect of decitabine on molt4 was mainly manifested as mitochondrial damage and the autophagosomal-like structure formation, and the degree of damage was concentration-dependent.

Decitabine downregulates mRNA levels PI3K/AKT/mTOR pathway components partly by upregulating PTEN expression. The RT-qPCR results showed that PI3K mRNA levels gradually decreased at decitabine concentrations $>10 \mu \mathrm{M}$ compared with those in the negative control group after $96 \mathrm{~h}$ of intervention. In addition, the mRNA levels of AKT, mTOR, p70S6 and 4EBP1 significantly decreased, when the cells were treated with decitabine concentrations $>1 \mu \mathrm{M}$. PTEN mRNA expression was upregulated in cells treated with 1 and $10 \mu \mathrm{M}$ decitabine but was downregulated after treatment with $50 \mu \mathrm{M}$ decitabine (Fig. 5 and Table III). Decitabine could downregulate mRNA levels PI3K/AKT/mTOR pathway with concentration increasing.

Decitabine downregulates levels of proteins involved in the PI3K/AKT/mTOR pathway. Western blotting results indicated that PTEN protein levels were slightly increased after $96 \mathrm{~h}$ of intervention with 1 to $50 \mu \mathrm{M}$ decitabine. However, the protein expression of PI3K, AKT, mTOR, total P70S6 and 4EBP1 was downregulated (Fig. 6 and Table SIII). However, only at
$50 \mu \mathrm{M}$ decitabine intervention, protein levels of mTOR, P70S6 and 4EBP1 had statistical difference compared with $0 \mu \mathrm{M}$. No other statistical difference was found. So, Decitabine downregulated levels of proteins involved in the PI3K/AKT/mTOR pathway at $50 \mu \mathrm{M}$ concentration.

\section{Discussion}

The present study demonstrated that decitabine can induce apoptosis and inhibit proliferation in molt4 cells. Cell cycle analysis showed that the majority of molt 4 cells were arrested in the $\mathrm{G}_{2}$ phase, indicating that the cells did not enter the mitotic phase, since they needed to repair damaged DNA after replication (21). In terms of affected subcellular structures, decitabine increased the production of lipid droplets and autophagosomes and promoted mitochondrial damage.

In the PI3K/AKT/mTOR signaling pathway, PI3K can phosphorylate PIP2 to PIP3. Moreover, PIP3 recruits and activates AKT (Ser 308 phosphorylation) as a secondary messenger. Following AKT activation, the mTOR complex is further activated to regulate protein synthesis $(22,23)$. The primary downstream effectors include ribosomal p70S6 and 4EBP1, which further promote cell proliferation, and invasion (24). PTEN can block the phosphorylation of PIP2 to PIP3, thereby preventing the activation of this pathway $(25,26)$. In the present study, analysis of PI3K/AKT/mTOR pathway showed that decitabine downregulated the mRNA expression of components involved in the pathway, including PI3K, AKT, mTOR, P70S6 and 4EBP1. In addition, PTEN mRNA expression was upregulated in cells treated with low decitabine concentrations of 1 and $10 \mu \mathrm{M}$. However, PTEN mRNA expression was downregulated at high decitabine concentrations of $50 \mu \mathrm{M}$. Higher decitabine concentrations caused a slight increase in PTEN protein levels and significantly downregulated the mRNA expression of PI3K, AKT and mTOR. Decreased 4EBP1 and 


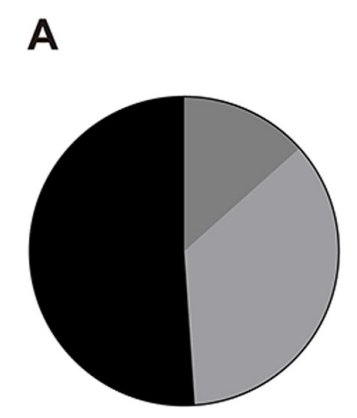

B
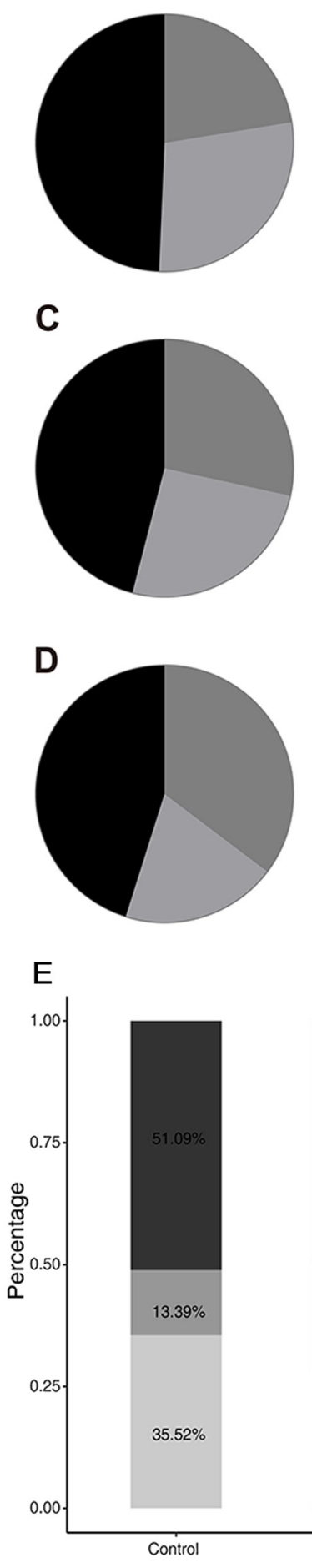

- $51.09 \% \mathrm{G} 1$ $\square 35.52 \% \mathrm{~S}$

$\square 13.39 \%$ G2

- $49.32 \% \mathrm{G} 1$ $\square 28.26 \% \mathrm{~S}$

$\square 22.42 \%$ G2
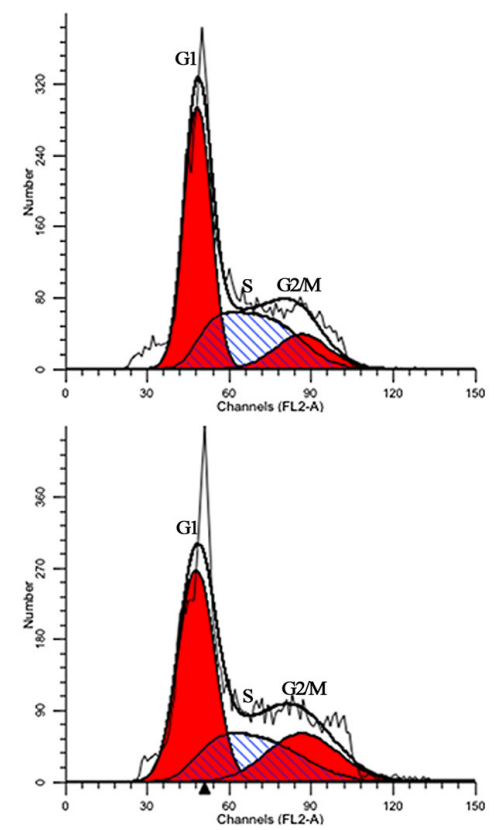

- $46.00 \% \mathrm{G} 1$ $\square 25.57 \% \mathrm{~S}$ $\square 28.44 \%$ G2

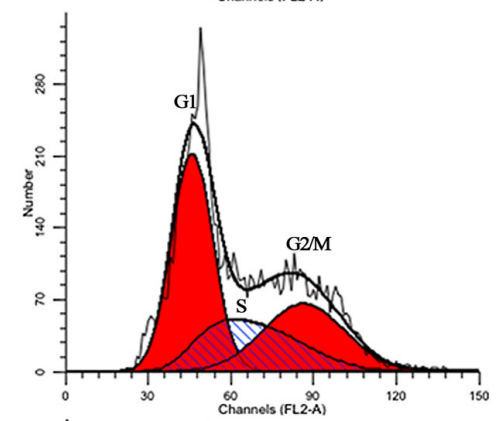

- $45.13 \% \mathrm{G} 1$ $\square 19.56 \% \mathrm{~S}$ $\square 35.31 \%$ G2
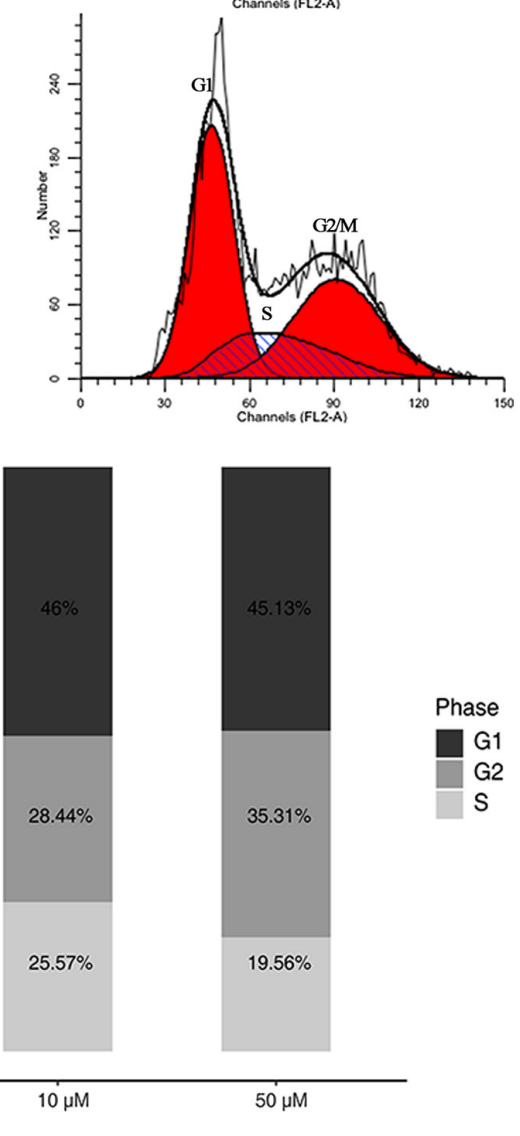

Figure 3. Effect of different decitabine concentrations on the cell cycle of molt4 cells at $96 \mathrm{~h}$. (A) Negative control. (B) $1 \mu \mathrm{M}$. (C) $10 \mu \mathrm{M}$. (D) $50 \mu \mathrm{M}$. The pizza chart shows the proportion of cells in each phase of the cell cycle. (E) Cell cycle of molt4 cells treated with decitabine at different concentrations for $96 \mathrm{~h}$ and detected using flow cytometry. 


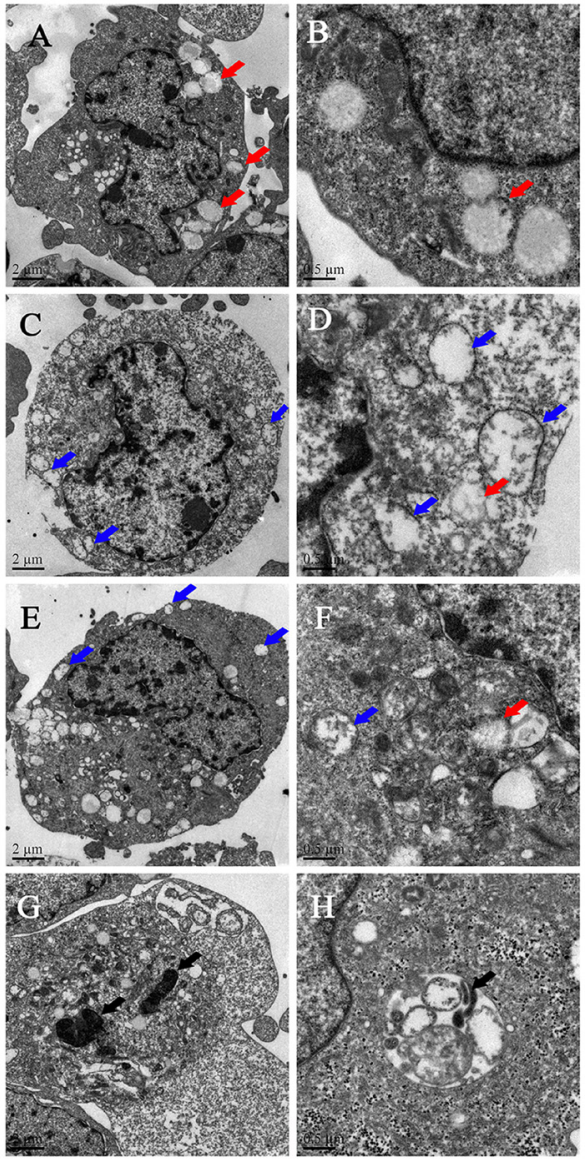

Figure 4. Subcellular morphology of molt4 cells after treatment with different decitabine concentrations for $96 \mathrm{~h}$ observed under a transmission electron microscope. (A and B) Negative control. (C and D) $1 \mu \mathrm{M}$. (E and F) $10 \mu \mathrm{M}$. (G and $\mathrm{H}$ ) $50 \mu \mathrm{M}$. The red, blue and black arrows indicate lipid droplets, mitochondrial damage and an autophagic body-like structure, respectively. Scale bar, 2 or $0.5 \mu \mathrm{m}$.

P70S6 expression in mRNA and protein levels also indicated that decitabine indirectly inhibited the PI3K/AKT/mTOR pathway. Therefore, altered PTEN mRNA expression does not completely explain the observed inhibitory effect of decitabine on the viability of molt4 cells. Overall, low decitabine concentrations may have upregulated PTEN mRNA expression by suppressing the methylation of PTEN DNA to inhibit the activity of the PI3K/AKT/mTOR pathway in molt4 cells, turn affecting cell proliferation and promoting apoptosis. At high decitabine concentrations, other mechanisms may exist that can regulate the $\mathrm{PI} 3 \mathrm{~K} / \mathrm{AKT} / \mathrm{mTOR}$ pathway and further influence the proliferation of molt4 cells. However, the biological effects of the slightly increased PTEN protein levels should not be overlooked, although no significant expression changes were observed.

In a previous study, $5 \mu \mathrm{M}$ decitabine treatment for 4 days increased the sensitivity of drug-resistant molt 4 cells to daunorubicin and doxorubicin, and downregulated the expression of ABCB1/P-glycoprotein (27). In present results, it indicated that the proliferative inhibition $\mathrm{IC}_{50}$ of decitabine was $84.461 \mu \mathrm{M}$ at $72 \mathrm{~h}$, and the $\mathrm{IC}_{50}$ was $10.113 \mu \mathrm{M}$ at $96 \mathrm{~h}$ of treatment, therefore prolonged treatment with decitabine requires a lower drug concentration to inhibit cell proliferation and promote apoptosis. Prolonging the duration of drug action
$(>96 \mathrm{~h})$ or increasing the concentration of decitabine $(>5 \mu \mathrm{M})$ could further inhibit cell activity. These results suggested that treatment with 5-10 $\mu \mathrm{M}$ decitabine for 4 days can inhibit the proliferation of molt 4 cells and increased the sensitivity of these cells to decitabine. These effects are further enhanced with a prolonged treatment time and higher drug concentration. However, in clinical applications, toxicity still needs to be considered, and low concentrations administered for long periods may potentially diminish the toxic side effects in normal cells $(28,29)$.

In another study, the proliferation inhibition rate of $0.5 \mu \mathrm{M}$ decitabine on molt 4 cells was $69.76 \pm 2.2 \%$ and the apoptotic rate was $37.75 \pm 3.87 \%$. Under these conditions, the percentage of $G_{0} / G_{1}$ cells was significantly increased. The lactotransferrin (LTF) gene was analyzed after screening for differentially expressed genes in the transcriptome. The methylation rate of the CpG sites of LTF gene promoter decreased from 72.3 to $45.0 \%$ after $72 \mathrm{~h}$ treatment with $0.5 \mu \mathrm{M}$ decitabine, which in turn upregulated LTF gene expression (30). The concentration of decitabine used in the present report was low with a short treatment period, but it effectively inhibited cell proliferation and promoted apoptosis. In the present study, the inhibition rate was $\sim 10 \%$ after $72 \mathrm{~h}$ of $0.5 \mu \mathrm{M}$ decitabine intervention, and the apoptotic rate ranged only between 2.27 and $20.90 \%$. In addition, LTF acts as a tumor suppressor protein that inhibits the proliferation and metastasis of tumors and is known to exert antimicrobial, anti-viral and immune regulatory effects (31-33). LTF expression levels are low in molt4 cells without decitabine intervention but were observed to significantly increase after intervention (30). Therefore, these results suggested that LTF expression plays a major role in the inhibition of cancer cells under short-term treatment with low concentrations of decitabine. The present results confirmed that 1 and $10 \mu \mathrm{M}$ decitabine can inhibit proliferation, promote apoptosis and induce $\mathrm{G}_{2}$ cycle arrest by increasing PTEN expression and inhibiting the PI3K/AKT/mTOR pathway in molt4 cells. However, the downregulation of PTEN expression decreased at $50 \mu \mathrm{M}$ decitabine, which suggested that the $\mathrm{PI} 3 \mathrm{~K} / \mathrm{AKT} / \mathrm{mTOR}$ pathway is not regulated via DNA methylation inhibition of the PTEN gene at relatively high decitabine concentrations. Other basic studies have showed that not only PTEN, but also Notch 1 (3) and RAS (34), can regulate the PI3K/AKT/mTOR pathway. Therefore, the upregulated expression of other TSGs could also be involved in the decitabine-induced decrease in the viability of tumor cells and regulation of the $\mathrm{PI} 3 \mathrm{~K} / \mathrm{AKT} / \mathrm{mTOR}$ pathway.

Various studies have indicated that different concentrations of decitabine are required to inhibit molt4 viability $(27,30)$. Therefore, other potential factors may affect the results, such as culture conditions, cell passage, cell activity and gene expression levels. In addition, the findings of the aforementioned studies and the present report indicate that decitabine exerts inhibitory effects on molt 4 cells in a time- and dose-dependent manner (30). The effect of decitabine on cells progresses over time and with increased concentrations. At low concentrations and short treatment times, decitabine preferentially acts on the more active DNA methylation genes that usually induce TSGs. At higher concentrations and prolonged treatment times, decitabine can inhibit a higher number of DNA methylation genes and consequently affect tumor cell viability (30). 
Table III. Reverse transcription-quantitative PCR results for PI3K/AKT/mTOR pathway and related gene expression in molt4 cells after treatment with different decitabine concentrations.

\begin{tabular}{lcccccc}
\hline Decitabine, $\mu \mathrm{M}$ & \multicolumn{1}{c}{ PI3K } & \multicolumn{1}{c}{ AKT } & mTOR & \multicolumn{1}{c}{ PTEN } & p70s6 & \multicolumn{1}{c}{ 4EBP1 } \\
\hline 0 & $1.000 \pm 0.014$ & $1.000 \pm 0.001$ & $1.000 \pm 0.007$ & $1.000 \pm 0.006$ & $1.000 \pm 0.008$ & $1.000 \pm 0.004$ \\
1 & $1.013 \pm 0.005$ & $0.983 \pm 0.002^{\mathrm{b}}$ & $0.968 \pm 0.002^{\mathrm{a}}$ & $1.034 \pm 0.007^{\mathrm{b}}$ & $0.981 \pm 0.006^{\mathrm{a}}$ & $0.967 \pm 0.011^{\mathrm{a}}$ \\
10 & $0.932 \pm 0.003^{\mathrm{a}}$ & $0.967 \pm 0.0004^{\mathrm{b}}$ & $0.943 \pm 0.006^{\mathrm{b}}$ & $1.001 \pm 0.007$ & $0.979 \pm 0.003^{\mathrm{a}}$ & $0.958 \pm 0.007^{\mathrm{b}}$ \\
50 & $0.929 \pm 0.001^{\mathrm{a}}$ & $0.937 \pm 0.014^{\mathrm{a}}$ & $0.928 \pm 0.001^{\mathrm{b}}$ & $0.952 \pm 0.009^{\mathrm{b}}$ & $0.952 \pm 0.010^{\mathrm{b}}$ & $0.931 \pm 0.006^{\mathrm{b}}$ \\
\hline
\end{tabular}

${ }^{\mathrm{a}} \mathrm{P}<0.05$ and ${ }^{\mathrm{b}} \mathrm{P}<0.01$ vs. $0 \mu \mathrm{M} .4 \mathrm{EBP} 1$, eukaryotic initiating factor $4 \mathrm{E}-$ binding protein 1 ; $\mathrm{PTEN}$, phosphate and tension homology.

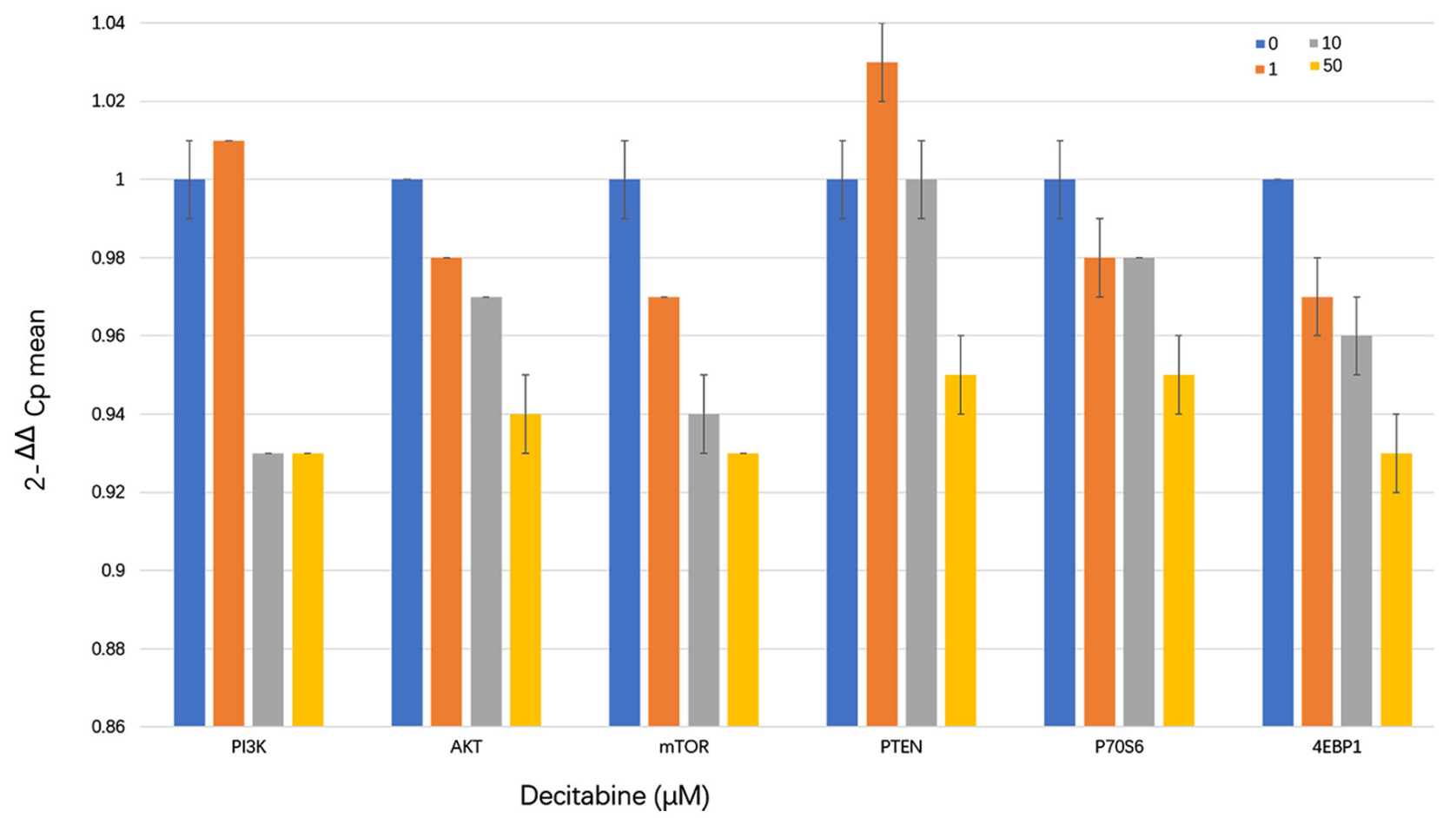

Figure 5. Reverse transcription-quantitative PCR detection of the PI3K/AKT/mTOR pathway and related gene expression in molt4 cells for different concentrations of decitabine. It indicated decitabine downregulates mRNA levels PI3K/AKT/mTOR pathway components partly by upregulating PTEN expression. Presented data are based on three independent experiments. Error bars indicate standard deviations.
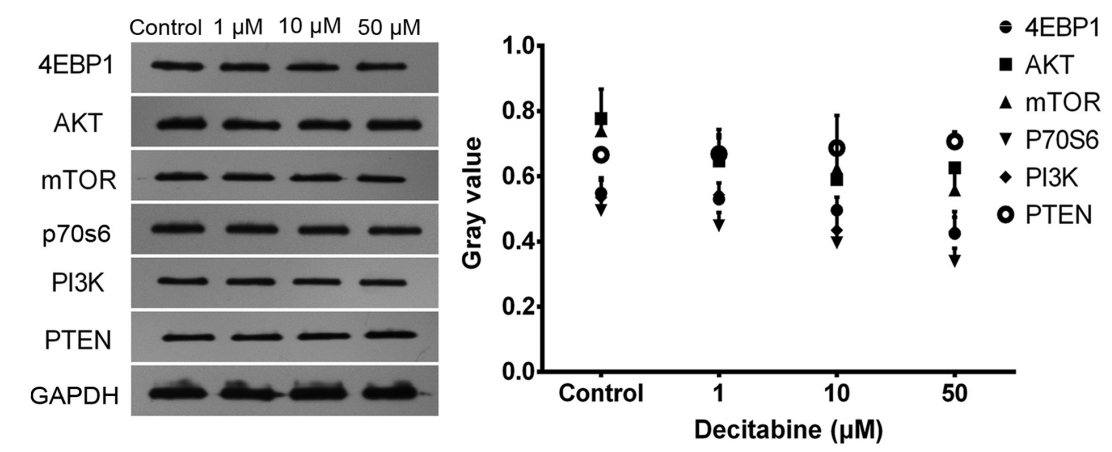

Figure 6. Effect of different decitabine concentrations on PI3K/AKT/mTOR pathway and related protein expression in molt4 cells. It indicated decitabine downregulates levels of proteins involved in the PI3K/AKT/mTOR pathway. Presented data are based on three independent experiments. Relative expression ratio of target proteins was calculated as follows: Relative expression ratio of target protein IOD/GAPDH IOD. IOD, integrated optical density.

Therefore, analyses based on epigenomics and transcriptome studies with a single concentration and at a single time point do not completely reflect the inhibitory mechanism of decitabine on tumor cells $(30,35,36)$. 
Previous findings demonstrated that decitabine exerts its effects on molt4 cells in a dose- and time-dependent manner $(27,30)$. The present study only analyzed changes in the gene expression of PTEN and genes involved in the $\mathrm{PI} 3 \mathrm{~K} / \mathrm{AKT} / \mathrm{mTOR}$ pathway, and did not detect the methylation levels of $\mathrm{CpG}$ sites and the phosphorylation levels of AKT and mTOR. Furthermore, epigenomics and transcriptome analyses were not conducted. Decitabine can markedly inhibit DNA methyltransferase (27). In further studies, transcriptome analyses will be performed to investigate gene expression in molt4 cells at different concentrations of decitabine and at different time points. The dynamic inhibitory effects of decitabine should be evaluated to elucidate the underlying mechanisms of function in molt4 cells and other T-ALL cell lines.

In conclusion, decitabine can inhibit cell proliferation, induce cell cycle arrest in the $\mathrm{G}_{2}$ phase and induce apoptosis in molt4 cells. Additionally, on the subcellular morphological level, decitabine can increase the production of lipid droplets and autophagosomes and induce mitochondrial damage. Decitabine intervention inhibited the activity of the PI3K/AKT/mTOR pathway, whereas PTEN levels were upregulated upon treatment with and $10 \mu \mathrm{M}$ decitabine. However, PTEN levels were downregulated after treatment with $50 \mu \mathrm{M}$ decitabine, which suggested the PI3K/AKT/mTOR pathway is not regulated via DNA methylation inhibition of the PTEN gene this concentration. The present results provided evidence to highlight the importance of investigating the dose and time-dependent effects of decitabine on molt4 cells.

\section{Acknowledgements}

The authors would like to thank Mr. Pang Shiwei for their comments and suggestions during the revision of the manuscript.

\section{Funding}

The study was funded by the Medical and Health Science and Technology Plan Project of Zhejiang Province (grant no. 2019KY693), the Jiaxing Key Discipline Fund (grant no. SY18-Z-06) and Hospital-Level Fund of the First Affiliated Hospital of Jiaxing University (grant no. 2016-YA-08).

\section{Availability of data and materials}

All data generated or analyzed during this study are included in this published article.

\section{Authors' contributions}

GZ and XJG designed the study and wrote the manuscript. GZ, XHG and XZ collected the data and performed the experiments. HW, MY and YL analyzed the data. HZ and ZJ analyzed and interpreted the data. All authors read and approved the final manuscript.

\section{Ethics approval and consent to participate}

Not applicable.

\section{Patient consent for publication}

Not applicable.

\section{Competing interests}

The authors declare that they have no competing interests.

\section{References}

1. Akkapeddi P, Fragoso R, Hixon JA, Ramalho AS, Oliveira ML, Carvalho T, Gloger A, Matasci M, Corzana F, Durum SK, et al: A fully human anti-IL-7R $\alpha$ antibody promotes antitumor activity against T-cell acute lymphoblastic leukemia. Leukemia 33: 2155-2168, 2019.

2. Teachey DT and Pui CH: Comparative features and outcomes between paediatric T-cell and B-cell acute lymphoblastic leukaemia. Lancet Oncol 20: e142-e154, 2019.

3. Hales EC, Taub JW and Matherly LH: New insights into Notch1 regulation of the PI3K-AKT-mTOR1 signaling axis: Targeted therapy of $\gamma$-secretase inhibitor resistant T-cell acute lymphoblastic leukemia. Cell Signal 26: 149-161, 2014.

4. Karrman K and Johansson B: Pediatric T-cell acute lymphoblastic leukemia. Genes Chromosomes Cancer 56: 89-116, 2017.

5. Rahmat LT, Nguyen A, Abdulhaq H, Prakash S, Logan AC and Mannis GN: Venetoclax in combination with decitabine for relapsed T-cell acute lymphoblastic leukemia after allogeneic hematopoietic cell transplant. Case Rep Hematol 2018: 6092646, 2018.

6. Fu JH, Yang S, Nan CJ, Zhou CC, Lu DQ, Li S and Mu HQ: MiR-182 affects renal cancer cell proliferation, apoptosis, and invasion by regulating $\mathrm{PI} 3 \mathrm{~K} / \mathrm{AKT} / \mathrm{mTOR}$ signaling pathway. Eur Rev Med Pharmacol Sci 22: 351-357, 2018.

7. Wang X, Han L, Zhang J and Xia Q: Down-regulated NRSN2 promotes cell proliferation and survival through PI3K/Akt/mTOR pathway in hepatocellular carcinoma. Dig Dis Sci 60: 3011-3018, 2015.

8. Silva A, Girio A, Cebola I, Santos CI, Antunes F and Barata JT: Intracellular reactive oxygen species are essential for PI3K/Akt/mTOR-dependent IL-7-mediated viability of T-cell acute lymphoblastic leukemia cells. Leukemia 25: 960-967, 2011.

9. Carnero A and Paramio JM: The PTEN/PI3K/AKT pathway in vivo, cancer mouse models. Front Oncol 4: 252, 2014.

10. Palomero T, Sulis ML, Cortina M, Real PJ, Barnes K, Ciofani M, Caparros E, Buteau J, Brown K, Perkins SL, et al: Mutational loss of PTEN induces resistance to NOTCH1 inhibition in T-cell leukemia. Nat Med 13: 1203-1210, 2007.

11. Medyouf H, Gao X, Armstrong F, Gusscott S, Liu Q, Gedman AL, Matherly LH, Schultz KR, Pflumio F, You MJ and Weng AP: Acute T-cell leukemias remain dependent on Notch signaling despite PTEN and INK4A/ARF loss. Blood 115: 1175-1184, 2010.

12. Ultimo S, Martelli AM, Zauli G, Vitale M, Calin GA and Neri LM: Roles and clinical implications of microRNAs in acute lymphoblastic leukemia. J Cell Physiol 233: 5642-5654, 2018.

13. Pan Y, Liu G, Zhou F, Su B and Li Y: DNA methylation profiles in cancer diagnosis and therapeutics. Clin Exp Med 18: 1-14, 2018.

14. Yang Y, Zhao L, Huang B, Hou G, Zhou B, Qian J, Yuan S, Xiao H, Li M and Zhou W: A new approach to evaluating aberrant DNA methylation profiles in hepatocellular carcinoma as potential biomarkers. Sci Rep 7: 46533, 2017.

15. Momparler RL, Côté S, Momparler LF and Idaghdour Y: Inhibition of DNA and histone methylation by 5-Aza-2'-deoxycytidine (Decitabine) and 3-deazaneplanocin-A on antineoplastic action and gene expression in myeloid leukemic cells. Front Oncol 7: 19, 2017.

16. Almasri J, Alkhateeb HB, Firwana B, Sonbol MB, Damlaj M, Wang Z, Murad MH and Al-Kali A: A systematic review and network meta-analysis comparing azacitidine and decitabine for the treatment of myelodysplastic syndrome. Syst Rev 7: 144, 2018.

17. He PF, Zhou JD, Yao DM, Ma JC, Wen XM, Zhang ZH, Lian XY, $\mathrm{Xu}$ ZJ, Qian J and Lin J: Efficacy and safety of decitabine in treatment of elderly patients with acute myeloid leukemia: A systematic review and meta-analysis. Oncotarget 8: 41498-41507, 2017.

18. Xie M, Jiang Q and Xie Y: Comparison between decitabine and azacitidine for the treatment of myelodysplastic syndrome: A meta-analysis with 1,392 participants. Clin Lymphoma Myeloma Leuk 15: 22-28, 2015. 
19. Uitdehaag JC, de Roos JA, van Doornmalen AM, Prinsen MB, Spijkers-Hagelstein JA, de Vetter JR, de Man J, Buijsman RC and Zaman GJ: Selective targeting of CTNBB1-, KRAS- or MYC-driven cell growth by combinations of existing drugs. PLoS One 10: e0125021, 2015.

20. Livak KJ and Schmittgen TD: Analysis of relative gene expression data using real-time quantitative PCR and the 2(-Delta Delta C(T)) method. Methods 25: 402-408, 2001

21. Shi P, Zhang L, Chen K, Jiang Z, Deng M, Zha J, Guo X, Li P and $\mathrm{Xu} \mathrm{B}$ : Low-dose decitabine enhances chidamide-induced apoptosis in adult acute lymphoblast leukemia, especially for p16-deleted patients through DNA damage. Pharmacogenomics 18: 1259-1270, 2017.

22. Simioni C, Martelli AM, Zauli G, Melloni E and Neri LM: Targeting mTOR in acute lymphoblastic leukemia. Cells 8: 190, 2019.

23. Bertacchini J, Heidari N, Mediani L, Capitani S, Shahjahani M, Ahmadzadeh A and Saki N: Targeting PI3K/AKT/mTOR network for treatment of leukemia. Cell Mol Life Sci 72: 2337-2347, 2015.

24. Fransecky L, Mochmann LH and Baldus CD: Outlook on $\mathrm{PI} 3 \mathrm{~K} / \mathrm{AKT} / \mathrm{mTOR}$ inhibition in acute leukemia. Mol Cell Ther 3 : $2,2015$.

25. Wang X, Huang $\mathrm{H}$ and Young KH: The PTEN tumor suppressor gene and its role in lymphoma pathogenesis. Aging (Albany NY) 7: 1032-1049, 2015.

26. Pulido R: PTEN inhibition in human disease therapy. Molecules 23: 285, 2018.

27. Onda K, Suzuki R, Tanaka S, Oga H, Oka K and Hirano T: Decitabine, a DNA methyltransferase inhibitor, reduces P-glycoprotein mRNA and protein expressions and increases drug sensitivity in drug-resistant MOLT4 and Jurkat cell lines. Anticancer Res 32: 4439-4444, 2012.

28. Atallah E, Kantarjian H and Garcia-Manero G: The role of decitabine in the treatment of myelodysplastic syndromes. Expert Opin Pharmacother 8: 65-73, 2007.
29. Bohl SR, Bullinger L and Rücker FG: Epigenetic therapy: Azacytidine and decitabine in acute myeloid leukemia. Expert Rev Hematol 11: 361-371, 2018.

30. Liu J, Huang C, Cheng H, Tang G, Hu X, Zhou H, Wang J and Yang J: Effects of decitabine against acute $T$ lymphoblastic leukemia cell line Molt4. Zhonghua Xue Ye Xue Za Zhi 36: 230-234, 2015 (In Chinese).

31. Deng M, Zhang W, Tang H, Ye Q, Liao Q, Zhou Y, Wu M, Xiong W, Zheng Y, Guo X, et al: Lactotransferrin acts as a tumor suppressor in nasopharyngeal carcinoma by repressing AKT through multiple mechanisms. Oncogene 32: 4273-4283, 2013.

32. Giansanti F, Panella G, Leboffe L and Antonini G: Lactoferrin from milk: Nutraceutical and pharmacological properties. Pharmaceuticals (Basel) 9: 61, 2016.

33. Drago-Serrano ME, Campos-Rodriguez R, Carrero JC and de la Garza M: Lactoferrin: Balancing ups and downs of inflammation due to microbial infections. Int J Mol Sci 18: 501, 2017.

34. Ksionda O, Melton AA, Bache J, Tenhagen M, Bakker J, Harvey R, Winter SS, Rubio I and Roose JP: RasGRP1 overexpression in T-ALL increases basal nucleotide exchange on Ras rendering the Ras/PI3K/Akt pathway responsive to protumorigenic cytokines. Oncogene 35: 3658-3668, 2016.

35. Kim YI, Park SW, Kwon HS, Yang HS, Cho SY, Kim YJ and Lee HJ: Inhibin- $\alpha$ gene mutations and mRNA levels in human lymphoid and myeloid leukemia cells. Int J Oncol 50: 1403-1412, 2017.

36. Davies C, Hogarth LA, Dietrich PA, Bachmann PS, Mackenzie KL, Hall AG and Lock RB: p53-independent epigenetic repression of the p21(WAF1) gene in T-cell acute lymphoblastic leukemia. J Biol Chem 286: 37639-37650, 2011.

This work is licensed under a Creative Commons Attribution-NonCommercial-NoDerivatives 4.0 International (CC BY-NC-ND 4.0) License. 